\title{
SUSTAINING THE UNIVERSITY OF JOHANNESBURG AND WESTERN SYDNEY UNIVERSITY PARTNERSHIP IN THE TIME OF COVID: A QUALITATIVE CASE STUDY
}

DOI: http://dx.doi.org/10.17159/2223-0386/2020/n24a5

Brett M Bennett

University of Johannesburg

Johannesburg South Africa

bbennett@uj.ac.za

\& Western Sydney University

Sydney, Australia

\& b.bennett@westernsydney.edu.au

Sameer Hifazat

Western Sydney University

Sydney, Australia

S.Hifazat@westernsydney.edu.au
Gregory A Barton

University of Johannesburg

Johannesburg South Africa

gregoryb@uj.ac.za

\& Western Sydney University

Sydney, Australia

\& G.Barton@westernsydney.edu.au

\author{
Basetsana Tsuwane \\ University of Johannesburg \\ Johannesburg South Africa \\ passiontsiwana@gmail.com
}

\author{
Laurence M Kruger \\ Kruger National Park (Skukuza) \\ Organization for Tropical Studies \& University of Cape Town \\ Cape Town, South Africa \\ laurence.kruger@tropicalstudies.org \& laurence.kruger@uct.ac.za
}

\section{Abstract}

This article offers a qualitative case study of how COVID has changed an existing international education partnership between the University of Johannesburg (UJ) in South Africa and Western Sydney University (WSU) in Australia which involves collaboration with the not-for-profit Nsasani Trust and focuses on sustainability. Before COVID, both universities ran joint student mobility programs in the Kruger National Park (KNP) and were developing further plans for staff mobility and co-developed postgrad programs involving residency in both countries. These plans changed as a result of the COVID pandemic, which started in early 2020. Societal responses to the COVID pandemic, including national border closures, have forced academics, administrators and students to reconsider how internationalisation programs function during and after the pandemic. Using a qualitative case study based on personal experience, we argue that pre-existing university-to-university connections built before COVID will sustain linkages, but that the previous structure of engagement based on physical mobility - can shift to new arrangements that can be 
run fully digitally or used to support limited mobility when international travel resumes in the future. We position the UJ-WSU relationship in the historical context of internationalisation to both highlight the enduring nature of international engagements and suggest that changes are required to make international education sustainable.

Keywords: Environmental History; Internationalisation; Study Abroad; Sustainable Development Goals.

\section{Introduction}

This article explores how the global outbreak of the novel COVID-19 coronavirus redirected international education efforts between the University of Johannesburg (UJ) and Western Sydney University (WSU). In Australia and South Africa, COVID responses included the temporary banning of international travel except for repatriation purposes, a shift to online teaching rather than face-to-face learning, and new financial pressures on universities caused by declining revenue streams. Universities are now turning their attention to core business, and internationalisation, like all areas, faces financial pressures, including budget cuts. Despite the challenges, UJ and WSU have expressed the desire to continue international linkages even though it may not be possible to sustain them, at least in the short-term, at previous levels of physical mobility or financial support. Nonetheless, new opportunities exist to expand coteaching opportunities with dual degrees, video conferences and electronic "exchange" of teaching and research in cost-effective ways that further expands the internationalisation mission of the universities involved.

This article offers a qualitative case study of how COVID has changed educational engagements between UJ and WSU. ${ }^{1}$ The administrations of both universities supported bilateral mobility of students and researchers. They launched a successful and growing internationalisation program of teaching, research and staff mobility between the two institutions that centres on the UN's Sustainable Development Goals (SDGs). Started in 2015, the program involved Australian students visiting Africa twice a year, joint collaboration by UJ and WSU staff and students, the development of a planned co-PhD, and trilateral engagements with Africa, Australia and China. This program, like every other form of internationalisation, has been changed significantly by COVID travel restrictions and society-wide shutdowns and social distancing measures.

1 RE Stake, “Qualitative case studies”, NK Denzin \& YS Lincoln (eds.), The Sage Handbook of Qualitative Research (Sage Publications Ltd, 2005), pp. 443-466. 
The research design of the study, based on personal experiences directing and engaging with bilateral student mobility and collaborative research, reflects the views of the authors, three professors and two MA students. The sections are divided into:

- a historical review of internationalisation trends;

- a case study of an overseas study trip based in the KNP which ran from 2015 to 2020 ;

- a case study of efforts to negotiate a co-badged postgraduate degree focused on sustainability. The historical background offers context for the two case studies. Our observations do not attempt to offer generalisations about the future of internationalisation but rather are meant to inform participants who are currently navigating international engagements.

\section{A history of Australian and South African internationalisation}

The current pause in international travel has had significant consequences for students, staff and institutions that had built up numerous mobilitybased components (e.g. student exchange, studying in person at foreign universities, etc.) of internationalisation. Online elements of internationalisation, though important, took something of a backseat at many institutions that prioritised person-to-person engagements. COVID has reversed this order, as seen in the case studies, and online is now the primary, and in some cases, the only means of maintaining linkages between institutions.

Human mobility has been the backbone of internationalisation efforts. International education can be traced before World War II, but the more modern incarnation emerged in the post-World War II era when a number of countries, including Australia, instituted government-sponsored programs of student exchange using the language of international cooperation. ${ }^{2}$ The American Fulbright program and Australia's Colombo plan - both which supported inbound and outbound flows of people - stand out as examples of government efforts to use study abroad for diplomacy. ${ }^{3}$ Australia developed a study abroad program to facilitate foreign relations with newly independent Asian nations. In his inaugural speech as Minister for External Affairs, Percy Spender warned the House of Representatives

2 SR Asada, 50 Years of US Study Abroad students: Japan as the gateway to Asia and beyond (London, Routledge, 2019), p. 15.

3 Fulbright US Student Program, "Fulbright US Student Program History" (available at https:// us.fulbrightonline.org/about/history, as accessed on 18 August 2020). 
on March 9, 1950 that "no nation can escape its geography ... we live side by side with the countries of South and Southeast Asia (and) it is in our interest to foster commercial and other contacts... and give them what help we can in maintaining stable and democratic governments in power". ${ }^{4}$ Welcoming Asian scholars to Australia through the Colombo Plan acted as a "watershed in Australia's cultural development". 5

The neo-liberal era of internationalisation, which emerged in the 1990s and continues to this day (albeit in a paused condition), redefined the purpose of study abroad. Many international education leaders argued that both nations and graduates needed to "compete" in the now globalized market whilst also maintaining cultural understanding necessary for cosmopolitan values. ${ }^{6}$ Economic globalization emphasised the need to produce graduates who could compete in an integrated global market. ${ }^{7}$ Universities in Australia and the United State of America (USA), for instance, recruited foreign students who paid higher fees and also fit within national skills-based migration policies.

Globally, 2018 became the year for the highest enrolment, with 5.6 million students crossing international borders to study in foreign institutions. ${ }^{8}$ Prior to COVID, Australia had one of the largest numbers of foreign students studying in any country in the world. The latest figures from the Australian Bureau of Statistics reveal that international education was worth $\$ 40.3$ billion for the Australian economy in 2019

4 House of Representatives Official Hazard, "Commonwealth of Australia parliamentary debates", 10(9), March 1950 (available at https://parlinfo.aph.gov.au/parlInfo/download/hansard80/hansardr80/1950-03-09/ toc_pdf/19500309_reps_19_206.pdf;fileType=application $\% 2 \mathrm{Fpdf} \#$ search $=\% 221950$ s $\% 201950 \% 20$ $03 \% 2009 \% 22$, as accessed on 10 August 2020), p. 628.

5 D Oakman, "Young Asians in our homes: Colombo plan students and white Australia", Journal of Australian Studies, 26(72), 2002, p. 98.

6 S Twombly, M Salisburg, S Tumant and P Klute, 2012, "Special issue: Study abroad in a new global century - Renewing the promise, refining the purpose", ASHE Higher Education Report, 38(4), In: S Asada, 50 Years of US study abroad students: Japan as the gateway to Asia and beyond (London, Routledge, 2019), p. 16.

7 M Shaw, Global society and international relations (Cambridge, Polity Press, 1994), In: S Twombly, M Salisburg, S Tumant and P Klute, 2012, "Special issue: Study abroad in a new global century ...", ASHE Higher Education Report, 38(4), In: S Asada, 50 Years of US study abroad students: ..., p. 16; S Mueller, "Globalization of knowledge", In: K Hanson, \& W Meyerson (eds.), International challenges to American colleges and universities: Looking ahead (Phoenix Arizona, American Council on Education/Oryx Press, 1995), In: S Asada, 50 Years of US Study Abroad students: ..., p. 16.

8 The Organization for Economic Cooperation and Development, Education at a glance 2020: OECD indicators, OECD Publishing (Paris, 2020), p. 228. 
compared to $\$ 32.4$ billion in $2017-2018 .^{9}$ In 2008 , there were 202,581 international students enrolled in the Australian Higher Education sector. ${ }^{10}$ International student enrolments in the Australian higher education sector peaked in 2019 with 442,219, an increase of 239,638 enrolments compared to 2008. Enrolments from China accounted for the largest foreign student enrolment in 2019 with 28 per cent. This is followed by India (15 per cent), Nepal ( 7 per cent) and Brazil (4 per cent). ${ }^{11}$ Australian students participating in overseas study abroad programs remain at high numbers: 52,171 Australian students participated in an overseas program in 2018, an increase of 2,908 compared to 2017. Statistics from 2018 also reveal China as the most preferred destination for Australian students at 14.7 per cent, followed by the USA (10.1 per cent) and UK (7.6 per cent). In 2017, China (11.2 per cent), the USA (11.1 per cent) and UK ( 8.3 per cent) were the same top three destinations for Australian students. ${ }^{12}$

Prior to the end of apartheid, South Africa remained somewhat isolated from internationalisation. In the late $1980 \mathrm{~s}$, South Africa's international student numbers were significantly lower ( 2 per cent or less of total population) than France, Germany or the USA. ${ }^{13}$ Most students came from Europe or from the white elite in neighbouring Southern African countries, although a contingent of black Zimbabweans also studied at South African universities.

South Africa's international student market has grown considerably since the end of apartheid in 1994 and the election of the first democratic government. In 2010, 66,113 students of foreign origins studied at a South African university. ${ }^{14}$ African students comprise the majority, with 46,191 from

9 Department of Education Skills and Employment, "Research snapshot July 2020, Education Export Income by country 2019" (available at https://internationaleducation.gov.au/research/Research-Snapshots/Documents/ RS\%20Education\%20export\%202019.pdf, as accessed on 21 August 2020); H Ferguson and H Sherrell, "Overseas students in Australian higher education: A quick guide", Parliament of Australia: Department of Parliamentary Services (available at https://www.aph.gov.au/About_Parliament/Parliamentary_Departments/ Parliamentary_Library/pubs/rp/rp1819/Quick_Guides/OverseasStudents, as accessed 21 August 2020).

10 H Ferguson and H Sherrell, "Overseas students in Australian higher education: ...", Parliament of Australia. ... (available at https://www.aph.gov.au/About_Parliament/Parliamentary_Departments/Parliamentary_ Library/pubs/rp/rp1819/Quick_Guides/OverseasStudents, as accessed on 21 August 2020).

11 Department of Education Skills and Employment, "Education Export Income by country 2019," July 2020 (available at https://internationaleducation.gov.au/research/research-snapshots/Documents/RS\%20 Education\%20export\%202019.pdf, as accessed on 21 August 2020).

12 Department of Education Skills and Employment, "International Mobility of Australian Students," April 2020, (available at https://internationaleducation.gov.au/ research/Research-Snapshots/Documents/RS_ Australian\%20student\%20mobility.pdf, as accessed on 21 August 2020).

13 S Rouhani and A Paterson, "Foreign students at South African universities", Development Southern Africa, 13(2), 1996, pp. 287-298.

14 Department of Higher Education and Training Republic of South Africa, "Green paper for post school education and training," January 2012 (available at https://www.saqa.org.za/docs/ papers/2012/greenpaper. pdf, as accessed 20 on August 2020). 
the Southern African Development Community (SADC) and 11,130 from elsewhere in Africa. Students from Europe $(3,653)$, Asia $(1,813)$ and North America $(1,737)$ comprised the largest non-African student populations. By 2013, nearly 74,000 foreign students, most of them $(53,800)$ from Southern African Development Community (SADC) studied at South African universities, comprising 7.5 percent of the total student population. ${ }^{15}$

The development of international policies came relatively late in South Africa. When the Department of Higher Education and Training (DHET) began considering international students as a source of income in 2015, it noted that the question had "to be explored with caution" because foreign students could constrain the available places for domestic students. ${ }^{16}$ South Africa's unequal development has created numerous problems. ${ }^{17}$ A DHET Green Paper highlighted the lack of national coordination in internationalisation. The Southern Africa Development Community Protocol on Education and Training operated as the DHET's only formal policy. The Green Paper noted, "while internationalisation is a reality at individual institutional level, it remains uncoordinated, piecemeal and ad hoc at national level". ${ }^{18}$ Moreover, inequality is still built into the system. DHET notes, "These linkages currently tend to be between the historically advantaged institutions and less so with historically black universities". ${ }^{19}$

In the past decade, Australia has embraced the African continent. Historically, Australia's governments have not prioritized the African region because of their focus on Asia. ${ }^{20}$ Study-abroad experts note that there had been a negative view in Western countries. Thankfully, this

15 Anon., "Annexure 2, Addressing systemic higher education transformation", Department of Higher Education and Training, Report on the second national higher education transformation summit international convention centre, Durban, KwaZulu-Natal 15-17 October 2015 (available at https://www. justice.gov.za/commissions/FeesHET/docs/2015-Report-SecondNationalHETSummit.pdf, as accessed on 20 August 2020), p. 14.

16 Department of Higher Education and Training of South Africa, "Green paper for post school education and training”, January 2012 (available at https://www.saqa.org.za/docs/papers/2012/greenpaper.pdf, as accessed 20 August, 2020), p. 52.

17 Department of Higher Education and Training of South Africa, "Green paper for post school education and training", January 2012 (available at https://www.saqa.org.za/docs/papers/2012/greenpaper.pdf, as accessed 20 August, 2020), p. 51.

18 Department of Higher Education and Training of South Africa, "Green paper for post school education and training", January 2012 (available at https://www.saqa.org.za/docs/papers/2012/greenpaper.pdf, as accessed 20 August, 2020),

19 Department of Higher Education and Training of South Africa, "Green paper for post school education and training", January 2012 (available at https://www.saqa.org.za/docs/papers/2012/greenpaper.pdf, as accessed 20 August, 2020), p. 51.

20 Advisory Group on Australia's engagement with Africa, “A strategy for Australia's engagement with Africa', Department of Foreign Affairs and Trade”, 2015 (available at https:/www.dfat.gov.au/about-us/ publications/Pages/a-strategy-for-australias-engagement-with-africa, as accessed on 14 August 2020). 
myopic view has been challenged in recent decades. ${ }^{21}$ The establishment the Australian-African Universities Network in 2012 added a new and important policy foundation. The Australian government shifted its attention towards Africa in the mid-2010s when the Federal Government launched the Australia-Africa Advisory Group on September 4, 2015.22 The foreign minister Julie Bishop added urgency to the group when she stated that Australia "cannot...ignore" the strategic and economic importance of the region. ${ }^{23}$ As interest in Africa soared, the need for educational engagement programs for both Australians and Africans became a strategic national priority.

These wider events coincided with the 2014 appointment of WSU's current Vice Chancellor, Professor Barney Glover, who encouraged study abroad. There has been a steady increase in overseas study since 2015 (Image 1). ${ }^{24}$ At WSU, one in six students participated in a study abroad program in 2018. This increase has occurred with the support of Go Global, the division within WSU responsible for mobility programs. Of these, 60 per cent of WSU students participated in an overseas program within the Indo Pacific region: with China (13 per cent) and India ( 8 per cent) the preferred destinations in the region. ${ }^{25}$ On a national scale study abroad programs in Africa accounted for 1.8 per cent of the total outbound Australian study abroad programs. ${ }^{26} \mathrm{At}$ WSU, this figure for the last few years has stood at around 6 per cent, some three times higher than the national average. ${ }^{27}$

21 M Pires, "Study-Abroad and Cultural Exchange Programs to Africa: America's image of a continent", African Issues, 28, 2000, p. 39.

22 Advisory Group on Australia's engagement with Africa, “A strategy for Australia's engagement with Africa", Department of Foreign Affairs and Trade, 2015 (available at https://www.dfat.gov.au/about-us/ publications/Pages/a-strategy-for-australias-engagement-with-africa, as accessed on 14 August 2020).

23 Advisory Group on Australia's engagement with Africa, "A strategy for Australia's engagement with Africa", Department of Foreign Affairs and Trade, 2015 (available at https://www.dfat.gov.au/about-us/ publications/Pages/a-strategy-for-australias-engagement-with-africa, as accessed on 14 August 2020).

24 Figures from Go Global, Western Sydney University. Please note data capture in 2014 was incomplete.

25 Western Sydney University, "Western Sydney University International Student Mobility 2018", 2018 (available at https://www.westernsydney.edu.au/_data/assets/pdf_file/0009/1618434/WSU_BLA_2018. pdf, as accessed on 14 August 2020).

26 Australian Government, Department of Education, Skills and Employment, "International mobility of Australian University students. International study experiences destinations regions and countries", 2018.

27 Western Sydney University, "Western Sydney University International Student Mobility 2018", 2018 (available at https://www.westernsydney.edu.au/_data/assets/pdf_file/0009/1618434/WSU_BLA_2018. pdf, as accessed on 23 August 2020) 
Image 1: Outbound Students at WSU University, 2015-2020

\begin{tabular}{|c|c|}
\hline Year & Outbound Students \\
\hline 2015 & 812 \\
\hline 2016 & 870 \\
\hline 2017 & 1019 \\
\hline 2018 & 1141 \\
\hline 2019 & 1100 \\
\hline
\end{tabular}

Source: Go Global (Western Sydney University's Go Global Division), 1 December 2020.

UJ's embrace of internationalisation gained impetus with the appointment of Professor Tshilidzi Marwala as Vice Chancellor in 2018. His appointment marked a strong emphasis on internationalisation, decolonisation and the $4^{\text {th }}$ Industrial Revolution. Professor Marwala has pursued a vision of making UJ and Africa a leader in the $4^{\text {th }}$ Industrial Revolution while also simultaneously promoting internationalisation and decolonising the institution from its apartheid past. UJ set a goal to have 20 per cent of staff be international by 2024, and 15 per cent of students as international by 2020 in order to provide a rich educational and research environment to support the domestic transformation agenda. ${ }^{28}$ International collaborations provide opportunities for South Africans that are not otherwise available domestically, and they also foster diplomatic links with key strategic partners, such as China, other African countries, and leading research nations, such as Australia and the USA. UJ's policy of internationalisation aims to increase the number of South African black academics and students while also maintaining other types of diversity. In this context, UJ looks to partner with diverse, large institutions, such as WSU that prioritise decolonization and transformation and also have similar academic and student profiles.

UJ and WSU share a number of common visions, the most important being the need to participate with the United Nations' Sustainable Development Goals (SDGs). The existing KNP study abroad trip and co-developed postgraduate degrees focus on sustainability. Furthermore, both institutions are committed to advancing the SDGs. In the 2019 Times Higher Education Sustainable Development Goals Ranking, WSU and UJ both rate in the

28 N Mabasa, "New Vice Chancellor plans to take the University of Johannesburg into the Fourth Industrial Age." Daily Maverick, 25 April 2018 (available at https://www.dailymaverick.co.za/article/2018-04-25-newvice-chancellor-plans-to-take-the-university-of-johannesburg-into-the-fourth-industrial-age/, as accessed 23. August 2020. 
top 5 for SDG 10 reducing inequalities (WSU \#3 and $\mathrm{U} \# 5$ ) due to their considerable research, teaching and community-engagement programs focusing on first-generation students. WSU's strengths in SDGs makes it an attractive partner for UJ due to Western's commitment to equality and development, keys for partnerships in Africa. UJ and WSU rates the top \#5 for gender quality, life on the land, clean water and sanitation and life below water, and responsible consumption and production. The SDGs inform UJ and WSU's ongoing collaborations.

\section{Case study one: From field-based to online learning}

COVID has challenged field-based study abroad options, such as the KNP trip that WSU has run with UJ and the Nsasani Trust in the Kruger since 2015. Like many international programs, the basis for WSU-UJ's collaboration began with person-to-person contacts that led to research and teaching. ${ }^{29}$ From 2011-2017, Bennett collaborated with the ecologist Dr Frederick J Kruger on a project focused on the history of forestry in South Africa. ${ }^{30}$ At the time, Kruger taught in the KNP with the U.S.-based Organisation of Tropical Studies (OTS) and the Nsasani Trust, a not-forprofit trust focusing on uplifting South African disadvantaged youth using science education. Bennett and Kruger developed the idea of running an immersive field seminar combining history, ecology, management and culture. The first class ran in July 2015 with 14 WSU students and every class since then (nine in total from 2016-2020) included UJ students. The Nsasani Trust, one of the three partners of the Skukuza Science Leadership Initiative (Along with SANParks Scientific Services and OTS), provided access to housing, arranged lectures and organised permits for research in the field. After Dr Kruger passed away in late 2017, Dr Laurence Kruger and Karen Vickers have led the African side of the teaching collaboration

29 The expertise and personal connections of individual faculty often inspire new programs relating to study abroad and research. See A Woldegiyorgis, D Proctor and H de Witt, "Internationalization of research: Key considerations and concerns", Journal of Studies in International Education, 22(2), 2018, pp. 161-176; M Kwiek, "What large-scale publication and citation data tell us about international research collaboration in Europe: changing national patterns in global contexts", Studies in Higher Education, 2020, pp. 1-21; M Kato and A Ando, "National ties of international scientific collaboration and researcher mobility found in Nature and Science", Scientometrics, 2020, pp. 673-694; S Kumar, V Rohani and K Rutnavelu, "International research collaborations of ASEAN Nations in economics, 1979-2010", Scientometrics, 2020, pp. 847-867; L Waltmann, R Tijssen and N Eck, "Globalisation of science in kilometres, 2012", Journal of Informetrics, 5(4), pp. 323-335; A Gazni, C Cussmido and F Didegah, "Mapping world scientific collaboration: Authors, institutions, and countries", Journal of the American Society for Information Science and Technology, 63(2), 2020, pp. 323-335; F Barjak and S Robinson, "International collaboration, mobility and team diversity in the life sciences: Impact on research performance", Social Geography, 3, 2008, pp. 23-36.

30 BM Bennett and Frederick J Kruger, Forestry and water conservation in South Africa: History, science and policy (Canberra: ANU Press, 2015). 
program on behalf of Nsasani.

The class takes a hands-on approach that requires learning in the field and the classroom and takes a mode two model that values knowledge from local scientists, lecturers and professors, game guards, community and even tourists. This immersive field-based experiential learning model combines field and classroom teaching, develops a transdisciplinary understanding of savanna ecology in students. The class starts literally from the ground up: we explore geology, natural history and evolution, human evolution and culture, and key historical processes. There is a strong focus on the engagement between the Park and the local communities, especially those in neighbouring Bushbuck Ridge and Hazyview municipal districts. This draws on SAN Parks' management approach which focuses on socioecological systems thinking: people and natural systems are inherently intertwined together. Environmental historians have been particularly influential in challenging the idea that humans and nature are separate, so the socio-ecological system fits well onto historical paradigms.

The class implements an interdisciplinary pedagogy that uses history to frame each subject. Subjects focus on fire, fencing, dispossession, migration, contemporary politics and ethical questions relating to the management of species and ecosystems. Students benefit from all majors and each can pursue a tailored and individual project from history, politics, philosophy, communication, psychology, management, law, science and more. Each of these disciplines relates to specific issues in the Park and can also be understood from a historical point of view. We focus on challenging questions: can we manage the park with a "hands-off policy?" Or: "who should have control and access to the park-locals, the nation or the world?" These are questions with legal, ethical, political, cultural and ecological dimensions that must be understood in light of the past. We also examine critical perspectives which see the Park as a space of privilege, question whether natural heritage deserves more emphasis than human heritage, and look at how tourism and social media shape the Park's policies.

South African students attend and also teach into the module. The trips average between three to four UJ students per trip. The trips also include South African research assistants, which include alumni. Having a diverse mix of students allows for exchange in perspective, and it facilitates intellectual decolonization by raising different and often challenging questions about the context, relevance and possible impact of Western 
'scientific' knowledge systems. Funding from WSU students to the Nsasani Trusts provides in-kind contributions to support South African students. This has amounted to over 30000 in-kind rand per student. This funding has supported 20 South African students on the trip. The Kruger has been an important feeder program for UJ's postgraduate history program, and three graduates have received the University's most prestigious GES 4.0 scholarship. The in-kind funding has also supported approximately 100 students for women in science and environmental monitoring programs.

With students inspired by their new experiences, the class transforms them psychologically as well as educationally. ${ }^{31}$ Students rate the Kruger trip among the highest of any classes offered at WSU (it has received the highest score of 5 for overall satisfaction), and feedback provided to the Nsasani Trust. A number of student quotes, used for a video (link found in notes), highlight key aspects of the experience. One student from science said: 'I think the style of learning is something that should be more widespread if possible. ${ }^{32}$

Another student remarked:

And that way of learning, I think, covers all different styles of learning. We supplied our own historians by virtue of them supervising the trip. But while we were there, we engaged with a couple of world leading scientists in their field, one a botanist, one an ecologist, and also the teaching assistants... .

The transdisciplinary nature of the experience especially impressed students:

The things we learned are not necessarily, you know, restricted to our own discipline. So, you know, there were students there, animal science students. There were historians, there were students of English, there was a philosopher. There were all kinds of different students... .

The $11^{\text {th }}$ trip planned for July 2020 was cancelled due to COVID. The first recognised outbreak of COVID in Wuhan, China in January 2020 and its global spread, including to Australia and South Africa, in February and March, sent a shockwave through international study abroad. Both Vice Chancellors called off all international trips and national borders shut to international tourists and visitors. Campuses shut, and students

31 J Raadik and S Cottrell, "Outdoor skills education: What are the benefits for health, learning and lifestyle?", World Leisure Journal, 62(3), 2020, pp. 219-241; M Asfeldt and G Hvenegaard, "Perceived learning, critical elements and lasting impacts on university-based wilderness educational expeditions", Journal of Adventure Education \& Outdoor Learning, 14(2), 2014, pp. 132-152.

32 Anon., "Kruger National Park", Western Sydney University YouTube Channel, YouTube, 14 Dec 2016 (available at https://www.youtube.com/watch?v=VgL5GIugIAk, as accessed on 10 August 2020). 
transferred to online learning. Interestingly, students continued to inquire about the trip into April and May. This suggests a strong desire to go overseas and it fits with evidence showing younger people feel more immune to COVID. ${ }^{33}$ Students under the age of 25 will certainly be a key driver of travel recovery because their rates of serious illness and death are significantly lower, and they have a higher risk appetite.

The cancellation of the class has had a serious down-stream impact on study abroad providers, such as the Nsasani Trust and other ancillary local contractors e.g. caterers and professional guides. The KNP effectively closed from late March until the Level 2 announcement on $15^{\text {th }}$ August 2020 that came into force midnight $17^{\text {th }}$ August 2020. The Trust has reopened by hosting a Women in Science class with students from local regions of Mpumalanga, which borders on the southern part of the KNP. One of their strategies for 2020 and into early 2020 is to host more local students. We hope to organise a UJ trip in 2021, assuming that COVID does not lead to lockdowns at level 3 or higher. The trip will rely on DHET publication subsidy funding.

We are all waiting to see what happens with international travel and the abatement of COVID-19. What does the future hold for field-based learning experiences? A number of options seem to be plausible, with some more desirable than others. The first option is that after the pandemic ends, we go right back running trips, and given enough time and the importance of study abroad experiences, this is the most appealing. But these transitions will, at best, take a number of years so other options must be considered. Australia may remain isolated longer than other countries, such as the USA, due to its low numbers of COVID. For instance, WSU extended a travel ban until 2021. South Africa, on the other hand, has had higher numbers of COVID cases than Australia, and it subsequently opened up its borders to non-citizens subject to a COVID test.

Can there be international interaction, field work, and the same interdisciplinary learning among staff and students without travel? We are developing an online module to offer immersive-type experiences that complement future study as well as an understanding of savanna

33 NSW Health, "In focus: COVID-19 in young adults (18-29 years). Reporting period: 1 January to 27 June 2020", 2020 (available at https://www.health.nsw.gov.au/Infectious/covid-19/Documents/covid-19-youngadults.pdf); W Yang, S Kandula, M Huynh, S Greene, G Van Wye, W Li, H Tai Chan, E McGibbon, A Yeung, D Olson, A Fine and J Shaman, "Estimating the infection fatality risk of SARS-CoV-2 in New York city during the spring 2020 pandemic wave: A model based analysis", The Lancet Infectious Disease, 19, 2020, pp. 1-10. 
ecosystems in both countries.

We are optimistic about providing digital opportunities but there are significant inequalities which students face. The digital space is a means to bring back some form of international education for students during and after the pandemic. Online international education can reach students who are unable to physically participate in international programs. Replicating international experiences online has challenges, the most pressing being access to data and connectivity. WSU and UJ both serve many first-generation students from lower socio-economic backgrounds. Both universities support students: WSU provided their students with laptops on loan and other technology to ensure students kept up with digital learning. In line with government advice, the university was able to keep their campus open for students who had difficulty accessing WIFI. ${ }^{34}$ UJ had a more difficult task of supporting students due to a stricter lockdown, greater inequality among students, and poor connectivity in townships and rural areas.

With campuses shut, many students lost access to resources such as libraries, computers and WIFI. As a result, UJ provided all their students with 30 gigabytes of free data. UJ also distributed over 1750 laptops for qualifying first year NSFAS students and 21,000 other devices for other qualifying students. ${ }^{35}$

Support schemes like this remain vital even after the reopening of international travel in a post-COVID world. Ensuring students, especially those that cannot fully afford physical travel have access to digital international experiences, might provide them with the opportunity to mix and interact with those in other regions. As Leask states, "the pandemic has highlighted how connected the world is and how important it is today, and will be in the future, that all graduates (and students alike) are able to work together across national and cultural boundaries as professionals and citizens, regardless of their ability to (physically) engage in mobility programs". ${ }^{36}$

34 Western Sydney University, "Student support," 2020 (available at https://www.westernsydney.edu.au/ coronavirus-information/students/student-support.html, as accessed on 15 October 2020); Western Sydney University, "Coronavirus: Frequently asked questions", 2020, (available at https://aem.westernsydney. edu.au/coronavirus-information/coronavirus-frequently-asked-questions.html, as accessed on 15 October 2020); Western Sydney University, "News and events," 2020 (available at https://www.westernsydney.edu. $\mathrm{au} /$ coronavirus-information/news-and-updates.html, as accessed on 15 October 202).

35 University of Johannesburg, "UJ committed to assisting students with access to devices and data", University of Johannesburg news and events, April 2020 (available at https://www.uj.ac.za/newandevents/ Pages/UJ-committed-to-assisting-students-with-access-to-devices-and-data.aspx, 15 October 2020).

36 B Leask, "Embracing the possibilities of disruption," Higher Education Research \& Development 39(7), 2020, p. 1390. 
Developing an online class catapulted the Nsasni Trust and Organisation of Tropical Studies into the digital world. Rapanta et.al note that COVID-19 is a "catalyst that highlighted the need for educational change towards more flexible models and practices that best respond to the complexity and unpredictability of today's fast and interconnected but and still fragile society". ${ }^{37}$ The Nsasani Trust via the Organisation of Tropical Studies, two organisations devoted to field-based study, had to develop online modules to continue teaching and develop revenue streams. These modules utilise research "practicums" which aim to bring the field to the students through innovative multimedia platforms, providing participants with practical research training, science writing skills and an immersive virtual field experience. The practicums, which run for 4 to 6 weeks, will explore the theoretical body of knowledge underpinning each topic and the relevance to contemporary conservation through lectures and discussions of key literature. Each course will comprise the following:

- In person lectures and videos from the field by staff and local experts.

- Discussion workshops led by participants and lecturers which explore the theoretical and conservation context for the challenge.

- A thorough exploration of the research design and how data are collected.

- Practical experience in remote data collection including, but not limited to, camera trap techniques and identification of animals from photos, parasite and vector identification, identification of data from automated recording units, application of data management and analysis platforms.

- Mentored data analysis and write up of chosen independent project

Practicums will provide students with an overview of emerging and conservation challenges, demonstrations of field sampling skills, realtime interactions with experts on the subject and experience in science writing. Participants will then have a good grounding in the field to begin their training in research techniques, remote/passive sample collection and processing, analytical and statistical approaches, and scientific writing. Practicums would be ideal for senior thesis or honours projects and provide the opportunity to contribute to an academic paper.

Students in Australia can take the module for credit via WSU faculty in coordination with the Trust. This is being discussed as one possible Collaborative Online International Learning (COIL) model, discussed

37 C Rapantha et.al., "Online University teaching during the and after the COVID-19 Crisis: Refocusing teacher presence and learning activity", Post Digital Science and Education, 2, 2020, p. 941. 
in the final section. This COIL changes our definition of study abroad, but crucially, it still involves student-centred learning, interdisciplinary teams, engagement and immersion in new cultures. Before COVID 19 hit, only two per cent of undergraduates in the United States were involved in international programs. ${ }^{38}$ An expanded application of the pedagogical tools used in traditional study abroad trips could include domestic experiences that still provide many of the same learning outcomes. It would have the unexpected benefit of transferring the same skills to students who would not normally have gone abroad due to a lack of resources or interest.

\section{Case study two: Building a joint postgraduate framework}

The second pillar of UJ-WSU relations, the creation of co-badged postgraduate study, is being similarly reshaped by COVID. In 2017, the Faculty of Humanities at UJ and the School of Humanities and Communication Arts WSU decided to forge a closer relationship by appointing two academics to work for half a year in each country. This relationship has led to a number of student exchanges, including UJ students studying in Australia and the exchange of a WSU student to UJ. Master's students Sameer Hifazat and Basetsana Tsuwane, authors on this article, have already done work in both countries and are keen to take advantage of the opportunities offered by co-badging postgraduate degrees.

Discussions to create postgraduate qualifications began before COVID but the focus has shifted since the pandemic started. The challenges of navigating a co-badged degree are idiosyncratic due to the complexities of administration, finance and law. Australia and South Africa both have requirements about what percentage of the degree must be done in each country, rules on residency, and the degrees that require equivalent subject matter. There is to our knowledge no single source which explains the various legal requirements different countries have on residency (i.e. how long does a student need to be in country), the different ways students pay for joint degrees (e.g. which university receives money and enrolls the student), and the arrangements required. All this has to be parsed out by staff and administration at each institution.

Both institutions have policies for dual MA and PhD degrees with foreign institutions. Section 4 of WSU's policy for joint-degrees emphasizes the

38 Anon., Opendoors data, "Fast facts- international students in the United States", 2019 (available at https:// opendoorsdata.org/fast_facts/fast-facts-2019/, as accessed on 10 August 2020). 
benefits of these arrangements: ${ }^{39}$

The doctoral or research master's candidate benefits under both dual award and joint degree arrangements in that the candidate has the opportunity to work and access the latest research equipment, facilities and expertise in more than one institution, and obtains awards that facilitate professional mobility. The advantages of such agreements extend beyond the benefit to the individual candidate and should be seen in the context of enhanced research cooperation between the institutions and the principal supervisors concerned.

An MOU signed in July 2019 by the Vice Chancellors at both Universities provides the basis for further formal arrangements to be made.

Initially, discussions focused on an MA in environmental history and/ or sustainability. Environmental history sits at the core of UJ-WSU relationship, but it is part of a larger collaborative relationship that includes sustainability, health, and the humanities. The original discussion focused on running a joint MA in environmental history. This would include a trip to the Kruger where students from both institutions would learn how to do interdisciplinary field work with scientists and communities based on the "mode two" learning model. To complete an assessment, we had to compare the different degree structure between WSU and UJ to determine equivalences.

WSU has multidisciplinary master's by research that includes disciplinary training but does not formally lead to an MA in history. The Master of Research (MRes) at WSU involves a one-year Bachelor of Research, a degree which replaced the old honours year (year 4), and then a one-year research by thesis MA. Students enrolled in the Bachelor of Research undertake core units in interdisciplinary methodology and select from electives across the university. In the second year, students undertake full-time research on a thesis in a specialization field (e.g. history, ecology, etc.).

UJ's degree progression fits the older style previously used by Australian universities. The history progression includes a three-year bachelor's in history or allied field, a fourth-year Honours in history or African studies, and then a two-year Master's by research. The history Honours to MA progression at UJ has greater research requirements and less of an emphasis on interdisciplinary or multidisciplinary training than does

39 Western Sydney University, "Western Sydney university dual award and joint higher degree research policy", 2019 (available at https://policies.westernsydney.edu.au/view.current.php?id=00200\#s1, as accessed 30 August 2020.) 
the MRes. At UJ there is no option for MA in history by coursework, but many staff and students desire this option. A coursework MA costs more to run because it requires a number of classes (a minimum of two per term). An MA requires either that faculty teach more or have a larger number of students to enroll to make it viable in terms of class size and finances. After doing an equivalence analysis, it became apparent that WSU's MRes catered better to a multidisciplinary framework than a strict disciplinebased model used by history at UJ.

The discussion then shifted towards creating a joint program on sustainability centred around the appointment of Senior Research Associates and Visiting Professors from WSU who specialized in sustainability and health. The visit of the WSU Vice Chancellor and ProVice Chancellor for International in July 2019, which included talks with the UJ Vice Chancellor and Deputy Vice Chancellor of Research and Internationalization, further cemented this relationship, and a research trip with staff working across the university was planned for in June 2020 focused on "Green Futures". Green Futures focused on urban and rural environmental sustainability, with a particular focus on vegetation and trees. WSU offered financial support and the trip became part of the University's planning for an Africa agenda in late 2019. Unfortunately, the outbreak of COVID in early 2020 cancelled this workshop, which required field visits in Johannesburg and around the Kruger. A threepart series between UJ and WSU has been developed to replace this workshop, but due to the field requirements of the first workshop, Green Futures has had to be delayed indefinitely.

Further meetings with international administrators identified challenges to be overcome to create a joint MA-MRes. First, an equivalence had to be created between degrees at both institutions. A new problem arose in that UJ lacked an equivalent multidisciplinary degree in sustainability. A new degree had to be created, which could take three years, or an existing degree would need to be modified. Up to 50 percent of any degree can be modified without having to register it with the Department of Higher Education and Training (DHET). There are a range of degrees which are "on the books" and approved by DHET but which are temporarily inactive. Ideally, the inactive degree has at least 50 percent which already fits the desired new degree (e.g., it allows for electives or has a core with the same focus). After many meetings and analysis, the Faculty of Humanities at UJ determined that it would be best to consider building a new degree. 
The problem of finances became one of the next immediate problems. How would students pay for the degree? What is seemingly a simple question is actually extremely difficult to answer. We wanted students to be able to enrol at their home institutions (e.g. for South Africans, UJ, and for Australians, WSU) in order to gain access to national loans/grants and to pay lower tuition costs as residents. Australian legislation meant that this model would not work. By Australian law, a student has to enrol and reside in Australia for joint degree purposes which raises the costs considerably. WSU's average tuition for a MA costs \$28,080 for 2020 whereas at UJ costs can be as low as 14,634 Rand (roughly \$1,200 AUD). ${ }^{40} \mathrm{WSU}$ offers special discounts, and even fee waivers, on a program-by-program and student-by-student basis.

Legislative requirements for Australia meant that South African students had to spend half the time in Australia. Conversely, Australian students had to spend half the time in South Africa. This would require money for tuition, travel and accommodation for one year of the two-year program. Australian students would have less trouble given the higher incomes in Australia (minimum wage is ten times more, \$20 AUD in Australia compared to 15.57 Rand, or \$1.30 AUD in South Africa), favourable exchange rate, and lower South African tuition. Despite this advantage, WSU students tend to come from lower socio-economic groups compared to other universities in Sydney and almost all have part-time jobs as do most UJ students. No government support exists for either country. Australian students can often access OS-Help, a government program that funds overseas study with up to $\$ 6,913$ AUD for study outside of Asia (more is given if one studies in Asia), but the structure of the Bachelors of Research and MRes means that students never receive the 80 credits (one year of full study) required to access OS-Help because each degree is technically a stand-alone for financial purposes. ${ }^{41}$

There is goodwill to discuss new options, but the Master's-level program is currently an issue to be worked out over the next year. The co-badged/joint

40 Western Sydney University, "Western Sydney university post grad 2020 international students education fees", August 2020 (available at https://www.westernsydney.edu.au/_data/assets/pdf file/0003/1565715/2020_INTL_Indicative_Fees_-_PG_-_7.8.20.pdf , last accessed 25 August 2020); "Cost attendance and distribution", University of Johannesburg, 2020 (available at https://www.uj.ac.za/ internationalstudents/Pages/Federal\%20Student\%20Aid/Cost-of-Attendance-and-Disbursements.aspx, as accessed on 20 August 2020).

41 "OS-help and overseas study", Australian Government Study Assist: Information for students about government assistance for financing tertiary studies, 2020 (available at https://www.studyassist.gov.au/ help-loans/os-help-and-overseas-study last accessed 19 August 2020). 
MA space is one that is still uncertain and in development. Both institutions have little track-record in this area due to the challenges mentioned above. WSU has only one joint agreement for the MRes. That program is funded by the Government of India with support from its elite Indian Institute of Technology group. In that arrangement, Indian students come to WSU for the second year of their MRes degree. UJ Humanities houses one joint MA with the University of West Indies, which pays for students to enrol at UJ as part of its agreement with UJ. In both cases, governments or universities fund the cost of student residency. MA programs, due to the

short timeframe and high financial and residency requirements, necessitate special funding and also close cooperation between institutions.

Attention then shifted towards a co-badged $\mathrm{PhD}$, which offered more flexibility and could be run across degrees (i.e. it did not require an agreement in one field). Early on in discussions, the Dean of Graduate Studies at WSU and the Internationalization Office at UJ suggested that the $\mathrm{PhD}$ might be an easier option. Had we heeded this advice earlier our lives would have been easier, but fewer lessons, many that have proven useful to other colleagues in our institutions, would have been learned.

The original intention of the MA sought to educate more students because more students study for MA than $\mathrm{PhD}$, and it could incorporate the Kruger training and also (we hoped) use OS-Help funding (which did not work out). After a year of planning and discussion, it became apparent that the $\mathrm{PhD}$ rather than MA provided a sounder financial and educational structure upon which to build our relationship.

Currently both institutions are finalizing negotiations, but COVID has caused significant delays in the implementation of the MOU and its rollout. WSU has suffered financial losses due to the decline in international student enrolments, and a freeze on all international travel has come into effect nationally. The two institutions must now work with constrained budgets. At the same time, the Australian Department of Foreign Affairs and Trade is reviewing Australian university MOUs in relation to foreign countries, particularly China, which has put significant pressure on international administrators and plans. UJ is currently less affected at an institutional level, but finances are also diminished and there is no international travel at this time. 
Right now, the plan is to start the first cohort of PhDs in 2022. Most of these students will come from history, although it anticipated that joint research in sustainability (including ecology) and health will lead to a number of projects that span disciplines in each institution. For instance, one of the authors of this paper is completing a master's and will likely undertake the dual $\mathrm{PhD}$ option in history. It is anticipated that travel bans will be lifted by 2022, possibly earlier, and that PhD-level travel might once again become possible. Current Australian foreign student residency requirements allow for online study to count for "residency" purposes during COVID so this clause could be enacted if required.

A series of workshops between UJ and WSU, which also includes Shanghai University, is helping to build momentum for the PhD among students and potential supervisors. UJ and WSU are hosting a three-part workshop on Humanities in the Time of COVID in late 2020 with a new theme focusing on sustainability in 2021. These digital workshops feature postgraduate and staff speakers and engage issues which are timely and relevant to both institutions and countries.

There are also ongoing discussions for a dual online module in environmental history, either at the undergraduate or postgraduate level. WSU passed a new university policy for Collaboration Online International Learning (COIL); currently the process is in stage 2, developing the concept. We are also examining classes and curiosity pods that align in time and content for undergraduates and postgraduates. A proposed honours and Masters of Research unit in environmental history is currently under discussion with a final agreement ideally settled by late 2020 or early 2021. Students would study with other students in joint online sessions that included individual break-outs in each country with local faculty.

Image 2: Stages of collaborative online learning at WSU

1. Discuss

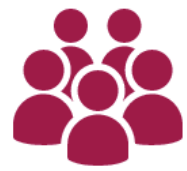

2. Develop Concept

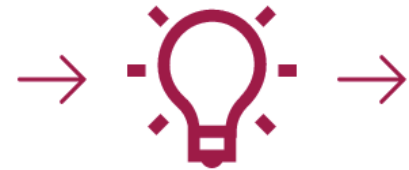

3. Meet International

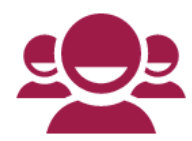

4. Submit Proposal

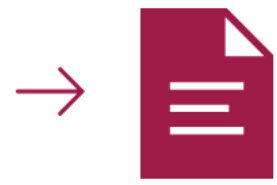

Source: Go Global (Western Sydney University's Go Global Division), 1 December 2020. 


\section{Conclusion}

As the two case studies describe, COVID has shifted plans for joint travel and degrees between UJ and WSU but it has not stopped planning. For obvious reasons, physical mobility has ended, hopefully temporarily, but it is likely that international travel trips will not return to the same level as prior to COVID for many years, if ever. This has significant implications for study abroad providers and not-for-profit organisations and local business which rely on funds from foreign students. The co-PhD arrangement can continue even with digital-only engagement due to the high-level work of $\mathrm{PhD}$ students and the increased supervisory capacity that dual arrangements create. Ideally physical mobility will return, but we must plan that its return will be slow and institutions will change. A number of digital initiatives will sustain - even grow - university-to-university and nation-to-nation arrangements until a new normal establishes itself. 